EESTI NSV TEADUSTE AKADEEMIA TOIMETISED 1954. III kd., nr. 1 ИЗВЕСТИЯ АКАДЕМИИ НАУК ЭСТОНСКОИ ССР 1954. Том III, № 1

\title{
ХРОМАТОГРАФИЧЕСКИЙ АНАЛИЗ СЛАНЦЕВЫХ МАСЕЛ
}

\author{
H. М. Томсон,
}

действительный член Академии наук Эстонской ССР

Жидкие продукты пиролиза органического вещества сланца содержат многоядерные ароматические углеводороды, среди которых обнаружено присутствие 3,4-бензпирена, обладающего раздражающими свойствами $(5,6,7,8)$. В процессах производства, транспортировки и использования этих жидких продуктов - сланцевых масел - рабочим приходится соприкасаться с ними.

Подобного же характера смолистые вещества образуются (при неблагоприятных условиях) как продукты неполного сгорания топлива, которые вместе с дымом и сажей загрязняют воздух городов и оказывают вредное влияние на все население.

Из-за раздражающих свойств смолистых веществ пришлось разработать методы их определения во внешней среде и выяснения характера их действия на организм.

Классический метод определения канцерогенных свойств смол и масел заключается в экспериментальном определении срока, по прошествии которого у мышей при систематическом смазывании кожи смолой возникает опухоль. Однако подобные опыты на мышах требуют значительного времени - до полутора лет $\left({ }^{2,3}\right)$, что ограничивает использование этого метода и заставляет искать другие, более быєтрые методы.

Бензпирен обладает свойством под действием ультрафиолетового света сильно флуоресцировать в синефиолетовой области спектра. На основе этого свойства в 1949 году при применении флуоресцентного спектрального анализа было обнаружено присутствие бензпирена в сланцевых маслах и в смолистых веществах, выделенных из дыма и сажи $(5,6,8)$.

Флуоресцентный спектральный анализ дает возможность быстро, в течение времени, измеряемого минутами, установить присутствие бензпирена. Но для проведения этого анализа необходимо иметь сложный прибор - спектрограф, что ограничивает возможность использования этого метода.

Определить присутствие бензпирена по флуоресценции можно более простыми средствами. Сланцевые масла имеют черный или темнокоричневый цвет и поэтому флуоресценция при непосредственном освещении фильтрованным ультрафиолетовым светом не может быть обнаружена. Для выделения флуоресцирующих веществ рекомендуется использовать хроматографический метод анализа по М. С. Цвету, открывшему этот метод в 1903 году. Хроматографический метод заключается в разделении сложных веществ на основе явлений адсорбции, различной растворимости компонентов смеси в растворителях и различного распределения состав- 
ных частей разделяемого вещества между двумя несмешивающимися растворителями. Сланцевые масла состоят из огромного количества ароматических, непредельных и кислородсодержащих веществ, и поэтому хроматографический метод вполне может быть применен для разделения масла на группы и отдельные химические соединения при движении через пористую среду под действием физико-химических свойств растворителя, среды и самого разделяемого вещества.

Различное распределение составных частей сложного вещества зависит от действия преимущественно одного из указанных выше факторов. В то же время нельзя отрицать одновременного действия всех других факторов при преобладающем действии одного фактора. Скорость движения растворителя и растворенного вещества зависит от материала пористой среды, размера пор и величины молекул, от образования соединений между составными частями разделяемого вещества и растворителя, явлений диффузии, адсорбции, коагуляции, образования осадков и т. д. По мере подъема растворителя концентрация его уменьшается и растворимость различных составных частей вещества изменяется по причине обеднения растворителем, обогащения наиболее растворимыми компонентами, вследствие чего растворенные вещества будут все больше выпадать в осадок. В то же время явления адсорбции могут препятствовать извлечению компонентов.

В качестве пористой среды для хроматографического анализа была использована фильтровальная бумага. Капля анализируемого масла наносилась в виде пятна величиной в диаметре не более 5 мм на полоску бумаги шириной 30 мм и длиной 300 мм. Полоска бумаги помещалась в стеклянный цилиндр высотой 360 мм и шириной 35 мм или же весь опыт проводился в пробирке (ширина бумажной полоски 15 мм и длина 150 мм). Полоска бумаги опускалась в небольшое количество (несколько куб. см) растворителя, наливаемого в цилиндр или в пробирку, закрываемые пробками. Под действием паров некоторых растворителей (эфир, хлороформ) масляное пятно расплывалось до величины $15-20$ мм.

Между восходящим и нисходящим методами бумажной хроматографии большой разницы обнаружено не было. Нисходящий метод давал такое же распределение веществ, как и восходящий, хотя растворитель передвигался несколько быстрее при первом методе. Чистый растворитель, без масляного пятна на бумаге, передвигался с такой же быстротой, как и с маслом, причем в последнем случае иногда наблюдалось даже незначительное ускорение. При более высокой температуре $\left(20^{\circ}\right)$ растворитель поднимался едва заметно быстрее, чем при более низкой $\left(5^{\circ}\right)$. Большое количество масла не влияло на изменение скорости передвижения растворителя, хотя само масло поднималось несколько медленнее. Влияние молекулярного веса растворителя, его удельного веса и температуры плавления и кипения выявить не удалось.

В первый момент растворитель огибал масляное пятно и двигался быстрее. В последующем растворенные вещества масла поднимались быстрее и догоняли (через $1-2$ часа) передний фронт растворителя.

Испытанные органические растворители по отношению к флуоресцирующим и другим составным частям сланцевого масла можно было разделить на пять групп.

Первая группа органических растворителей показала отставание флуоресцирующих веществ от общей массы составных частей масла, имеющего на бумаге цвет от желтого до темнокоричневого в зависимости от природы растворителя. Отставание флуоресцирующих веществ показали спирт, бензин и фенол (рис. 1). 
Вторая группа растворителей показала одинаковое движение растворителя и масла вместе с флуоресцирующими веществами, которые в виде узкой бледной каймы двигались позади желтокоричневого пятна (флуоресцирующие вещества на рисунках показаны пунктиром). К этой группе относятся бензол, дихлорэтан, хлороформ, эфир, толуол и пиридин.

Третья группа органических растворителей - скипидар и керосин показали совместное движение всей массы пятна, причем флуоресцирующие вещества окаймляли движущееся пятно со всех сторон. В дальнейшем флуоресцирующие вещества обгоняли общее пятно и уходили вперед, в случае скипидара в виде широкой и яркой полосы впереди пятна, до пе-

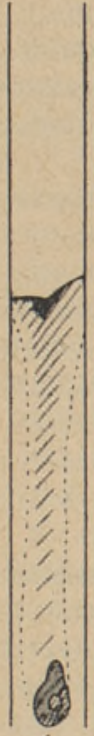

1
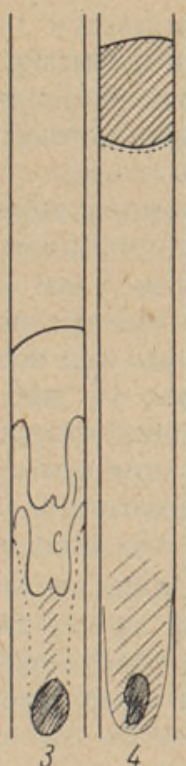

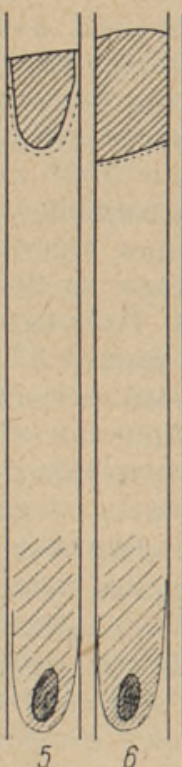

5
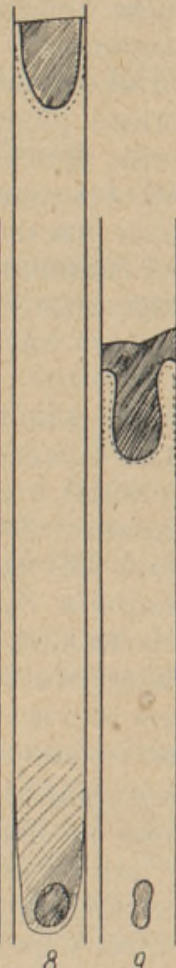

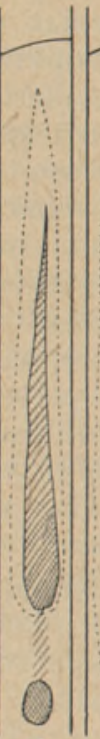

11

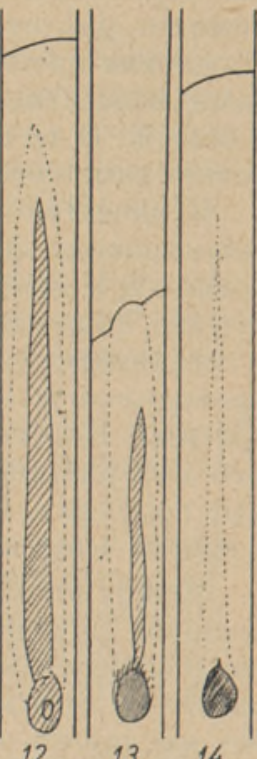

13

Рис. 1. 1 - спирт, 2 - бензин, 3 - фенол, 4 - бензол, 5 - дихлорэтан, 6 - хлороформ, 7 - эфир, 8 - толуол, 9 - пиридин, $10-$ скипидар, $11-$ керосин, 12 - спирт, 13 - глицерин, 14 - формальдегид.

реднего фронта растворителя, а в случае керосина флуоресцирующие вещества не достигали переднего фронта.

Четвертая группа органических растворителей - метиловый спирт и глицерин - показали совместное движение масла и флуоресцирующих веществ, причем последние окаймляли движующееся пятно и не отрывались от первоначального пятна, нанесенного на бумагу. При метиловом спирте движение пятна отставало от переднего фронта движения растворителя, а флуоресцирующие вещества уходили вперед. В случае глицерина флуоресцирующие вещества двигались вместе с передним фронтом растворителя, а остальные вещества (желтого цвета) отставали от переднего фронта. (Хроматограммы на рисунках даны за два часа, за исключением хроматограммы с глицерином, которая дана за 24 часа.)

Пятая группа органических растворителей была представлена только одним формальдегидом, который показал движение только одних флуорес- 
цирующих веществ, отстававших от переднего фронта движения растворителя, вся же масса желтых и коричневых веществ масла совсем не поднималась.

При испытании действия различных растворителей при одном и том же масле (тяжелая фракция камерного масла) можно было констатировать изменение цвета пятен от черного до серого, бледнорозового, бледнозеленого, желтого и коричневого. Наблюдение флуоресценции при фильтрованном ультрафиолетовом свете необходимо производить тотчас же. После высыхания полоски бумаги флуоресценция слабеет и через несколько дней исчезает вследствие испарения ароматических соединений.

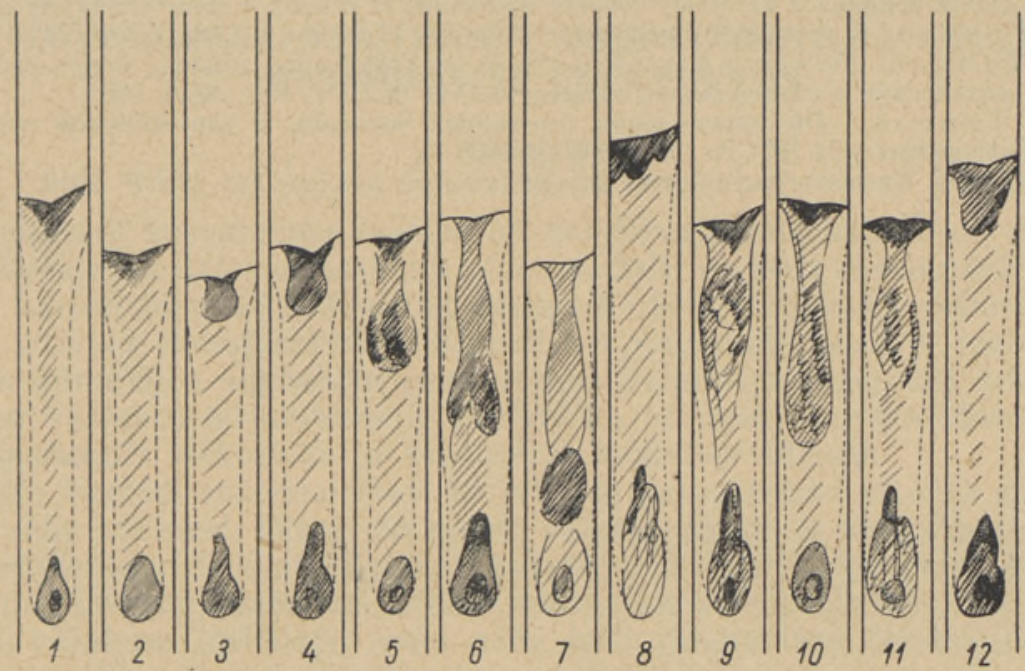

Рис. 2. 1 - камерное масло, тяжелая фракция, 2 - камерное масло, легкая фракция, 3 - генераторное масло, тяжелая фракция (5ГГС), 4 - генераторное масло, легкая фракция (5 ГГС), 5 - генераторное масло, тяжелая фракция (4ГГС), 6- генераторное масло, легкая фракция (4ГГС), 7 - генераторное масло, тяжелая фракция (3 ГГС), 8 - генераторное масло, легкая фракция (3 ГГС), 9 - масло из декантера, 10 - масло из фусоотделителя, 11 - масло из холодильника, 12 - масло из эксгаустера

Приведенные на рис. 2 хроматограммы получены при испытании различных масел в спирте. Они показывают сходную картину в отношении тяжелых и легких фракций из одного источника. Наиболее сильную флуоресценцию показали образцы $1,2,9-12$. Из растворителей спирт и скипидар (рис. 1) дали наиболее яркую флуоресценцию, то есть наилучшее выделение флуоресцирующих веществ из общей массы окрашенных соединений смол.

Таким образом, для экспресс-анализа смолообразных веществ на присутствие бензпирена по флуоресценции может быть с успехом применен хроматографический метод $М$. С. Цвета. Кроме того, хроматографический метод при сравнении различных смол дает возможность получить общее представление о составе их на основании картины распределения цветных пятен.

Поступила в редакцию 5 III 1954 


\section{ЛИТЕРАТУРА}

1. Б. П. Гуринов, В. А. 3 оре, А. А. Ильина и Л. М. Ш аб ад, О содержании полициклических ароматических уғлеводородов в загрязнениях атмосферного воздуха и в дымовых выбросах, «Гигиена и санитария», № 2, 1953.

2. Л. Ф. Л ар ионов, Н. Г. Соболев а и Л. М. Шаб а д, О канцерогенном действии некоторых сланцевых смол, «Вестник рентгенологии и радиологии», № $1-2,1934$.

3. Л. Ф. Л ар ионов, О канцерогенных свойствах смол из эстонских сланцев, Труды Ленинградского научно-исследовательского института гигиены труда и профзаболеваний, 1947.

4. В. В. Р а ч и н с к и й, Бумажная хроматография, «Успехи химии», вып, 4, 1950.

5. Н. М. Томсон, Загрязнение атмосферного воздуха продуктами неполного сгорания топлива и их гигиеническое значение, «Гигиена и санитария», № 2, 1950.

6. Н. М. Том с он, К вопросу о профилактике рака, «Гигиена и санитария», № 11, 1951.

7. Н. М. Т о м сон, Методика флуоресцентного спектрального анализа некоторых ароматических углеводородов, «Известия АН ӘССР», т. I, № 3, 1952.

8. Н. М. Том сон, Об определении смолистых веществ в задымленном воздухе, «Известия АН ЭССР», т. II, № 2, 1953.

9. М. С. Ц в е т, Хроматографический адсорбционный анализ, АН СССР, 1946. 